\title{
The Effectiveness of STEM for Sea Project to Improve Cadets' Performance as Preparation for Onboard Training
}

\author{
Okvita Wahyuni ${ }^{1}$, Iing Mustain ${ }^{2}$ \\ ${ }^{1}$ Semarang Merchant Marine Polytechnic (Politeknik Ilmu Pelayaran Semarang), Singosari 2 a, \\ Semarang, 50242, Central Java, Indonesia \\ ${ }^{2}$ Cirebon AKMI Suaka Bahari Merchant Marine Academy (AKMI Suaka Bahari Cirebon), Jenderal Sudirman \\ $156^{\text {th }}$, Cirebon Regency, West Java, Indonesia
}

\begin{abstract}
The use of technology plays an important role in education as we gradually move to what is known as industry 4.0. It becomes more important especially during COVID-19 pandemic where online learning is highly demanded. This research applied online learning using the application of STEM for Sea Project (SforSP) to improve the performance of cadets of CASBMMA (Cirebon AKMI Suaka Bahari Merchant Marine Academy), the preparation of their onboard training. This finding encourages the researchers to upgrade the application in providing more suitable materials which correspond to the company's needs during on board training.
\end{abstract}

Keywords - STEM Sea Project application (SforSP), onboard training, preparation.

\section{Introduction}

The development of various learning media is in line with the increase of technological advances.

The utilization of telecommunication technology for learning activities in the universities (Minister of Education Decree, 2001) encourages the

DOI: $10.18421 /$ SAR44-2

https://doi.org/10.18421/SAR44-02

Corresponding author: Okvita Wahyuni, Semarang Merchant Marine Polytechnic (Politeknik IImu Pelayaran Semarang), Semarang, Central Java, Indonesia. Email: okvita@pip-semarang.ac.id

Received: 29 September 2021.

Revised: 04 December 2021.

Accepted: 11 December 2021.

Published: 27 December 2021.

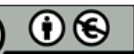

(C) 2021 Okvita Wahyuni \& ling Mustain; published by UIKTEN. This work is licensed under the CC BY-NC 4.0.

The article is published with Open Access at www.sarjournal.com conventional tertiary institutions to organize an effective distance education system. Moreover, COVID-19 pandemic in 2020 enforces all levels of education to employ technology to proceed distance teaching and learning process. Several universities have carried out various online learning activities for lectures including (a) lecturing, (b) joining various trainings on electronic learning material development, (c) assigning some tasks, and (d) carrying out some daily and term tests for students.

In this case, e-learning becomes one of the possible methods which can be used for distance learning. Elearning is an innovation not only to deliver the learning materials but also to improve the various competencies of the cadets of CASBMMA (Cirebon AKMI Suaka Bahari Merchant Marine Academy). Through e-learning, students do not only listen to the material descriptions but also actively observe, perform, demonstrate, download, and upload their own leaning materials. The material can be virtualized in various formats to make them more interesting and dynamic. Thus, cadets will be more motivated to go further in the learning process [7].

The Science, Technology, Engineering, and Mathematics (STEM) approach in education has been developed in various countries. It is based on The US Department of Technology, Engineering, and Mathematics (STEM) Education which says that the 5-Year Education Strategic Plan issued by the National Science and Technology Council (STEM Education Committee) identifies five main educational investment areas of STEM including generating 1 million STEM scholars in 10 years, increasing the number of women participating in STEM as they are unfortunately significantly underrepresented, designing Postgraduate Education for future STEM personnel with basic and applied research expertise, providing special skills in the areas of national interest to supply the needs for a workforce for STEM agencies, and providing the 
additional skills needed to be successful in multiple careers [8].

Onboard training is an integral part of education and training activities for officer candidates working on commercial vessels as required or standardized by STCW (Standards Training Certification and Watchkeeping for Seafarers) 1995 Regulation II/I and Regulation III/I. This training is a follow up activity and implementation of both the theoretical knowledge during the classroom learning and skills during the practice in the laboratory/workshop. Thus, hopefully the cadets will be able to have a concrete overview of how working on board is supposed to be.

One of the main duties and responsibilities of a cadet is learning. Thus, their learning process should be encouraged and supported. Knowledge, mental, and physical aspects are what a cadet needs unless he would fail and be eventually dismissed. Cadets need a strong mentality to face the pressure they would face onboard in order to be able to survive and complete the on-board training.

This research is focused on the performance of cadets in the preparation of onboard training through a process of guidance and direction which needs to be improved. Thus, it is necessary to develop methods of learning, coaching, and supervised for the cadets on the aspects of knowledge and skills such as the ability to complete the Cadet Record Book before joining on board training [15]. Through this research, STEM for Sea Project (SforSP), a web-based online learning application, has been developed. Thus, the cadets preparation can be possibly carried out through e-learning.

SforSP is a web-based learning application developed through the web of CASBMMA and can be accessed on https://stemprala.or.id/login/index.php. This application uses Moodle as an online learning application which can accessed by both lecturers and cadets. The application provides some learning materials and tests as the preparation of the on training.

Table 1. Diagram of Research Design

\begin{tabular}{lccc}
\hline Group & (Pre Test) & Cloud STEM Approach & (Post Test) \\
\hline Experiment & $\mathrm{O}$ & $\mathrm{X}$ & $\mathrm{O}^{\prime}$ \\
\hline
\end{tabular}

The data were analyzed using statistical tests which include: a) a normality test using One Sample Kolmogorov Smirnov Test which applied SPSS application program, b) a test of homogeneity of variance using Levene test using SPSS application program, and c) statistical tests to determine the
Onboard training has to be completed by each cadet for at least a year. This training is an integral part of education and training activities for Merchant Officer candidates as required or standardized by STCW 1995 Regulation II/I and Regulation III/I. This activity is the follow up activity and the implementation of both the theoretical knowledge they learned in the classroom and skills during the practice in the laboratory/workshop, so the cadets have a concrete overview of how working on board is supposed to be.

The research was aimed to analyze the effectiveness of using SforSP to prepare the cadets' onboard training, to analyze the increase in the cadets' performance after using SforSP, and to analyze the response of the cadets in using SforSP.

\section{Methodology}

This research applied a quasi-experimental method with experimental design used in the form of randomized control group of pretest and posttest. In the first stage, a pre test was carried out. Then, the cadets received a treatment through learning process [16]. The treatment for technical cadets was carried out by means of teaching and practicum/simulation. After that, a post test was held to identify the cadets' performance after receiving the treatment. The research design is shown in Table 1.

A survey was also carried out to identify the cadets' responses in using SforSP. The survey and questionnaire were delivered through Google form. These responses were then used as qualitative data. In this research, cluster sampling technique was applied by considering the cadets' level of semester. The samples were taken from more than 30 cadets from several classes of Nautical and Engineering department

The use of SforSP in preparing the cadets for their onboard training was carried out in two stages: a) creating cadets's accounts to access SforSP, and b) providing the learning material including a pretest and a posttest. There were 5-6 meetings held through SforSP where cadets learned about the materials to prepare them for the on board training. mean difference of the normally distributed data and the homogeneous data. To this data, parametric test was applied: paired samples t-test. On the other hand, data which were not normally distributed and were not homogeneous were analyzed using nonparametric test, Mann-Whitney $U$ test for independent samples. This test applied SPSS application program. 
In order to determine the onboard cadets' achievement, a paired sample t-test was applied based on the average score of the pretest and the posttest. On the other hand, in order to determine the increase of the cadet's performance, normalized gain score $\left(\mathrm{N}_{\text {gain }}\right)$ was used by applying the formula shown as follows [5]:

$\mathrm{N}_{\text {gain }}=\frac{\% \mathrm{~S}_{\text {post }}-\% \mathrm{~S}_{\text {pre }}}{100 \%-\% \mathrm{~S}_{\text {pre }}}$

The classifications of $\mathrm{N}_{\text {gain }}$ are as follows: a) high $\left(\mathrm{N}_{\text {gain }}>0.7\right)$, b) moderate $\left(0.3 \leq \mathrm{N}_{\text {gain }} \leq 0.7\right)$, and low $\left(\mathrm{N}_{\text {gain }}<0.3\right)$.

The effectiveness of using SforSP in improving the performance of the cadets was also analyzed. The analysis used Cohen's equation whose formula is as follows [1]:

$$
\begin{aligned}
& d=\frac{\overline{x_{1}}-\overline{x_{2}}}{S_{g a b}} \\
& S_{g a b}=\sqrt{\frac{\left(n_{1}-1\right) S_{1}^{2}+\left(n_{2}-1\right) S_{2}^{2}}{n_{1}+n_{2}-2}}
\end{aligned}
$$

where: $d=$ value of effect size, $\overline{\mathbf{x}}_{\mathbf{1}}=$ average value of pretest, $\overline{\mathbf{x}}_{\mathbf{2}}=$ average value of post test, $\mathbf{S}_{\mathbf{g a b}}=$ combined variance of pre test and post test, $\mathbf{S}_{\mathbf{1}}=$ variance of pre test, $\mathbf{S}_{\mathbf{2}}=$ variance of post test, $\mathbf{n}_{\mathbf{1}}=$ total sample of pretest, $\mathbf{n}_{\mathbf{2}}=$ total sample of post test.

In order to analyze the survey via Google form, an interval scale was employed. For the purposes of qualitative analysis, the interval scale uses the following categories: Strongly Agree (SA), Agree (A), Enough (E), Disagree (D), and Strongly Disagree (SD). Then, percentages were made in order to analyze qualitatively.

\section{Results and Discussion}

E-learning is defined as an information and communication technology intended to enable learners to study anytime and anywhere [2]. Elearning includes teaching and learning activities which are supported and developed through technology and digital media. E-learning is also a form of the concept of distance learning [6]. Nowadays, in universities, e-learning is highly required to support the teaching and learning process.

The terminology itself has various definition due to the varieties of its uses today. Basically, e-learning is divided into two types: synchronous and asynchronous. Synchronous is defined as 'at the same time' meaning that the learning process of both educators and students occurs at the same time which allows direct interactions between educators and students online.

In the implementation, synchronous training requires educators and students to access the internet simultaneously. Educators provide learning materials in form of papers or presentation slides to which students can listen directly via the internet. Students can also ask questions or give comments directly or via the chat window. Synchronous training is portrayed as a real class, but it is virtual where students are all connected to the internet. Synchronous training is often referred as virtual classrooms.

On the other hand, asynchronous means 'not at the same time'. In this type of e-learning, students are able to manage their own learning time as the lectures had provided the materials before. Asynchronous training is popular in e-learning because students can access learning material anywhere and anytime. Students can join the learning and complete it at any time according to a predetermined schedule range. Learning activities includes reading, animation, simulation, educational games, tests, quizzes, and assignments.

E-learning systems and applications are often regarded as Learning Management Systems (LMS), software systems which virtualize conventional teaching and learning processes for administration, documentation, reports on training programs, classrooms and online events, e-learning programs, and training content. They include all features related to the management of teaching and learning process such as classroom management, material or content creation, discussion forums, scoring systems, and online examination system which are all accessible through the internet.

E-learning content is defined as the teaching material in the LMS. This content and teaching materials can be in form of multimedia-based content or interactive multimedia content such as learning multimedia which allows us to use mouse and keyboard to operate it or text-based content such as textbooks on wikipedia.org, computer science.com. The materials are usually posted in the LMS and are accessible for the students anytime and anywhere.

On the other hand, the main actors in the implementation of e-learning are just the same with the conventional teaching and learning process: (a) the teachers (lecturers) to guide the students (learners) who receive teaching materials, and (b) the administrators who are responsible of administrative matters and the teaching and learning process. Elearning can possibly lead to a new atmosphere in the learning developments. The effective use of elearning can improve the learning outcomes optimally. 
Some of e-learning's benefits include (1) it shortens the learning time and decreases the study cost, (2) it enables the interaction between students and the material, (3) students are able to share information with each other and access the learning materials anytime repeatedly so that their comprehension to the learning materials is increased, (4) the process of knowledge developmenet does not only occur in the classroom; by the help of computer and network equipment, students can be actively involved in the learning process [14].

There are some general characteristics of online learning. These characteristics are based on a combination of several theories and approaches which support the online learning. The characteristics of online learning are very broad but in general, according to Flinders University, they include personal, structured, active, and connective.

One of the advantages of online learning is that students are able to create their own comfortable and desired learning atmosphere. Students do not need to be busy going to campus on time. This type of learning enables the students to manage their the learning time, place, atmosphere, and etc based on their preference. In the online learning process, we can learn personally and independently. There are several internal and external factors which influence the success of online learning. Internal factors include intelligence, high curiosity, motivation, personality, and etc. Meanwhile, external factors include the technology, the environment, the internet speed.

In this research, 36 cadets of Nautical and Engineering department had participated and completed the pre test and posttest. Table 2 shows the difference of the pretest and post test results based on the mean value and variance. It is shown that after receiving the online learning treatment through SforSP, the performance of the cadets increased.

The learning treatment through SforSP included providing the online learning for three to four meetings besides the pretest and posttest activities. It means that cadets will be able to access the first meeting, the second, the third, and the fourth meeting after completing the previous activity process.

Table 2. Achievement of Sea Project Ability Between Pretest and Posttest

\begin{tabular}{ccccc}
\hline No & Statistical measurement & Posttest & Pretest & Number of Samples \\
\hline 1. & Total score & 224.99 & 199.01 & 36 \\
2. & Average score & 6.25 & 5.53 & 36 \\
3. & Standard deviation & 1.35 & 1.61 & 36 \\
4. & Variations & 2.59 & 1.82 & 36
\end{tabular}

For example, cadets could join the first lesson if they had completed the pre test. They could access the second lesson if they have completed the first lesson, and so on. Thus, the learning can be completed up to the post test. The post test was held after the cadets completed all the learning activities.

One of the assumptions which are often tested in quantitative research is the fulfillment of the analyzed data which are normally distributed or not normally distributed and the homogeneity test. After that, a test to identify the difference of the means was carried out. The normality test uses the Kolmogorov Smirnov using SPSS with the test criteria: if significance (sign) $\geq \alpha$, the data is normally distributed, but if sign $<\alpha$, the data is not normally distributed. Both of these criteria use a significance level $(\alpha)=0.05$.

The normality test of the average value of pretest and posttest was carried out using SPSS version 23. The results of the normality test of the average value are shown in Table 3. The analysis showed that the significance reached 0.200 and 0.197 . This result was greater than the significance level $(\alpha)=0.05$ which can be concluded that the average scores of cadets' performancein the pretest and post test was normally distributed.

Table 3. Normality Test of Pretest and Posttest

\begin{tabular}{|c|c|c|c|c|c|c|}
\hline & \multirow{3}{*}{ Test } & & ts of Norn & & \multirow{3}{*}{ Analysis } & \multirow{3}{*}{ Note } \\
\hline$\alpha=0.05$ & & & ogorov-Sm & & & \\
\hline $\mathrm{n}_{\text {cadets }}=36$ cadets & & Mean & Deviation & Sign & & \\
\hline \multirow{2}{*}{ Sea project ability } & Pre test & 5.53 & 1.611 & 0.200 & $\operatorname{Sign} \geq \alpha$ & Normal \\
\hline & Post test & 6.25 & 1.349 & 0.197 & $\operatorname{Sign} \geq \alpha$ & Normal \\
\hline
\end{tabular}

This homogeneity test was also carried out to determine whether the research groups had a homogeneous or non-homogeneous variance with the significance level $(\alpha)=0.05$. The test analyzed the average value of the cadets' performance in the pretest and posttest using Levene statistics in SPSS. 
The test criteria are as follows: if the significance $\geq$ $\alpha$, both groups are considered as homogeneous while if sign $<\alpha$, both groups are regarded as nonhomogeneous.
The homogeneity of variance test results is shown in Table 4. It was found that the significance was 0.453 which was greater than the significance level $\alpha$ $=0.05$. Thus, it can be concluded that the variance was homogeneous.

Table 4. Homogeneity Test of the Pre Test and Post Test

\begin{tabular}{|c|c|c|c|c|c|}
\hline \multicolumn{6}{|c|}{ Test of homogeneity of variances } \\
\hline \multicolumn{4}{|c|}{ Sea project ability } & \multirow{2}{*}{ Analysis } & \multirow{2}{*}{ Note } \\
\hline Levene statistic & $\mathrm{df}_{1}$ & $\mathrm{df}_{2}$ & Sign & & \\
\hline 0.569 & 1 & 70 & 0.453 & Sign $\geq \alpha$ & Homogen \\
\hline
\end{tabular}

Based on the results of the normality test and the homogeneity test, it was found that the data were normally distributed and had homogeneous variances. Thus, in order to test the hypothesis, twosample t-test or statistic-test (paired t-test samples) could be employed. The test criteria are accepted if $\mathrm{H}_{0} \geq \alpha$ and are rejected if $\mathrm{H}_{0}<\alpha$. Both of these criteria use a significance level $(\alpha)=0.05$.
The results of the hypothesis test are shown in table 5. Based on the table, the results of the paired sample t-test in the sign (2-tailed) column or significance for two paired-sample is 0.000 . Based on the analysis, the significance value was found smaller than the significance level $(\alpha) 0.05(0.000$ $<0.05)$. Thus, $\mathrm{H}_{0}$ was rejected and $\mathrm{H}_{\mathrm{a}}$ was accepted meaning that the posttest performance of the cadets' performance was significantly greater than the pretest performance.

Table 5. Paired Sample t Test

\begin{tabular}{|c|c|c|c|c|c|}
\hline \multicolumn{6}{|c|}{ Paired samples test } \\
\hline \multicolumn{6}{|c|}{ Paired differences } \\
\hline \multirow{3}{*}{$\begin{array}{l}\text { Pair } 1 \text { Pretest - } \\
\text { Posttest }\end{array}$} & \multicolumn{2}{|c|}{$95 \%$ Confidence interval of the difference } & \multicolumn{3}{|c|}{ t-test for equality of means } \\
\hline & Lower & Upper & $\mathrm{t}$ & $\mathrm{d}_{\mathrm{f}}$ & Sig. (2-tailed) \\
\hline & -1.01260 & -0.43073 & -5.036 & 35 & 0.000 \\
\hline
\end{tabular}

The effectiveness of the t-test was 0.32 . This value was based on the effectiveness criteria of small category. The increase of the cadets' achievement based on the pretest and posttest through SforSP is shown in Table 6. Based on the analysis, $\mathrm{N}_{\text {gain }}$ reached $16 \%$ and was categorized as low.

Table 6. $N_{\text {gain }}$ Score of The Cadets' Performance

\begin{tabular}{cccc}
\hline & \multicolumn{2}{c}{ Experiment class } \\
\hline & $\mathrm{N}$ & Average & Deviation standards \\
\hline Pre test & 36 & 5.53 & 1.61 \\
\hline Post test & 36 & 6.25 & 1.35 \\
\hline $\mathrm{N}_{\text {gain }}$ score & \multicolumn{3}{c}{$16 \%$} \\
\hline
\end{tabular}

Table 7. The Results of Cadets's Questionnaire

\begin{tabular}{clll}
\hline No. & \multicolumn{1}{c}{ Questions } & $\begin{array}{c}\text { Cadets answer } \\
(\% \max )\end{array}$ & $\begin{array}{c}\text { Cadets answer } \\
(\% \mathrm{Min})\end{array}$ \\
\hline 1. & Guidance activities for pre on board training cadets are needed & SA $(74.1 \%)$ & $\mathrm{D}(1.9 \%)$ \\
\hline 2. & $\begin{array}{l}\text { SforSP developed by CASBMMA helps the cadets to prepare } \\
\text { their on board training }\end{array}$ & SA $(61.1 \%)$ & $\mathrm{D}(3.7 \%)$ \\
\hline 3. & $\begin{array}{l}\text { The material presented in SforSP helps the cadets to prepare the } \\
\text { knowledge needed in on board training }\end{array}$ & $\mathrm{SA}(55.6 \%)$ & $\mathrm{C}(5.6 \%)$ \\
\hline 4. & $\begin{array}{l}\text { SforSP is a solution to increase the cadets' knowledge about on } \\
\text { board training }\end{array}$ & $\mathrm{SA}(55.6 \%)$ & $\mathrm{D}(3.7 \%)$ \\
\hline 5. & $\begin{array}{l}\text { SforSP application has positive impact to the cadets who will } \\
\text { join on board }\end{array}$ & $\mathrm{SA}(59.3 \%)$ & $\mathrm{D}(3.7 \%)$ \\
\hline 6. & The material and knowledge in SforSP is very relevant to the & $\mathrm{SA}(46,3 \%)$ & $\mathrm{D}(3.7 \%)$ \\
\hline
\end{tabular}




\begin{tabular}{|c|c|c|c|}
\hline & needs of companies & & \\
\hline 7. & $\begin{array}{l}\text { We feel that SforSP is a solution which provides guidance and } \\
\text { knowledge needed by the cadets before on board training }\end{array}$ & SA $(51.9 \%)$ & $\mathrm{D}(3.7 \%)$ \\
\hline 8 . & $\begin{array}{l}\text { The material in SforSP is not in relevant with the company's } \\
\text { needs so we found it hard to understand }\end{array}$ & $\operatorname{SD}(33.3 \%)$ & $\mathrm{E}(5.6 \%)$ \\
\hline \multirow[t]{2}{*}{9.} & $\begin{array}{l}\text { In our opinion, SforSP does not make a positive contribution in } \\
\text { preparing our on board training }\end{array}$ & $\operatorname{SD}(42.6 \%)$ & $\mathrm{E}(3.7 \%)$ \\
\hline & We think SforSP is difficult to use & $\mathrm{SD}(57.4 \%)$ & $4(5.6 \%)$ \\
\hline
\end{tabular}

Note: $1 . \mathrm{SA}=$ Strongly Agree; $2 . \mathrm{A}=$ Agree; $3 . \mathrm{E}=$ Enough; $4 . \mathrm{D}=$ Disagree; $5 . \mathrm{SD}=$ Strongly Disagree

The cadets' responses on the use of SforSP were obtained through questionnaire using the Google form. The results are shown in Table 7. Based on the questionnaire, maximum percentages and minimum percentages were obtained.

Based on the survey, as shown in Table 7, the results indicated a positive response that more than $55 \%$ said that they strongly agree to the use of the application while more than $59 \%$ of the cadets gave positive responses. Meanwhile, $1.9 \%$ of the cadets claimed that SforSP is not necessarily needed to prepare the onboard training.

Based on the analysis on the increase of the cadets' performance, an increase in the average value the cadets' performance after learning using SforSP was found eventhough the increase was categorized as low. These results indicate that the application, in the aspect of knowledge, is able to help the cadets in preparing their onboard training. During the online learning activities, SforSP enables the cadets to access learning materials anywhere and anytime. According to the application, the cadets are able to determine and manage their own learning activities including the time, place, atmosphere, and conditions they desire. In addition, during COVID-19 pandemic, it is required that the cadets have to study at home. It was found that the results of this research supported the previous studies [11], [9], [3].

Students' achievement in leaning chemistry using e-learning media with a guided inquiry approach is claimed to be better than using the conventional methods [10], [17]. The implementation of e-learning during learning activities are able to improve student learning outcomes [13]. Based on the results of the data analysis, it was found that the effect size of using SforSP reached 0.32 and was regarded as small. Nevertheless, even this small effect size provided reinforcement to the cadets [4].

In order to increase the effect size, blended learning is necessarily required [12].

Based on the questionnaires via Google form, positive and negative responses were found. The findings are as follows: $74.1 \%$ of the respondents said that SforSP was highly required, $61.1 \%$ of them stated that SforSP helped them to prepare the on board training, $59.3 \%$ gave positive responses, $46.3 \%$ of the respondents stated that the materials were corresponding to the company's needs, and $51.9 \%$ of them said that SforSP was a solution in providing guidance and knowledge needed by the cadets before their onboard training. The finding related to the correspondence of learning materials and the companies's needs has encouraged the researchers to upgrade materials.

\section{Conclusion}

Based on the research, it is concluded that the elearning activities through SforSP had increased the the cadets' performance with a low category. This increase helped the cadets to prepare their onboard training. The effectiveness of using SforSP in improving the cadets' performance was categorized as low. However, the use of SforSP still had positive effect in preparing them to the onboard training. According to the cadets' responses to the use of SforSP, the application was regarded as good, positive, soluble, and relevant. Nevertheless, SforSP needs to be improved and upgraded in terms of the materials according to the needs of the company. 


\section{References}

[1]. Cohen, J. (1998). Statistical power analysis for the behavioural sciences, xxi. Hillsdale, NJ: L Erlbaum Associates.

[2]. Dahiya, S., Jaggi, S., Chaturvedi, K. K., Bhardwaj, A., Goyal, R. C., \& Varghese, C. (2016). An eLearning System for Agricultural Education. Indian Research Journal of Extension Education, 12(3), 132135.

[3]. Elyas, A.H. (2018). The use of e-learning models in improving the quality of learning. Jurnal Warta, 56, 111. [in Indonesian]. https://doi.org/10.46576/wdw.v0i56.4.

[4]. Fransisca, M., \& Yunus, Y. (2019). Efektivitas ELearning Tingkat Sekolah Menengah Atas Kota Padang. Indonesian Journal of Computer Science, 8(2), 113-120. https://doi.org/10.33022/ijcs.v8i2.174

[5]. Hake, R. R. (1998). Interactive-engagement versus traditional methods: A six-thousand-student survey of mechanics test data for introductory physics courses. American journal of Physics, 66(1), 64-74. https://doi.org/10.1119/1.18809.

[6]. Hakim, A. B. (2016). Efektifitas Penggunaan ELearning Moodle, Google Classroom Dan Edmodo. vol, 2, 1-6.

[7]. Hartanto, W. (2016). Penggunaan e-learning sebagai media pembelajaran. Jurnal Pendidikan Ekonomi: Jurnal Ilmiah Ilmu Pendidikan, Ilmu Ekonomi dan Ilmu Sosial, 10(1), 1-15.

[8]. Holdren, J.P., Marret, C., \& Suresh, S. (2013). Federal science, technology, engineering, and mathematics (STEM) education 5-year strategic plan. National Science and Technology Council: Committee on STEM Education.

[9]. Ibrahim, Doni Septumarsa; Suardiman, Siti Partini. Pengaruh Penggunaan E-Learning Terhadap Motivasi Dan Prestasi Belajar Matematika Siswa Sd Negeri Tahunan Yogyakarta. Jurnal Prima Edukasia, 2(1), 66-79. https://doi.org/10.21831/jpe.v2i1.2645.
[10]. Muazizah, N.M., Nurhayati, S., \& Cahyono, E. (2016). The Effectiveness of using Moodle-based elearning approaching guided inquiry on student learning outcomes. Jurnal Inovasi Pendidikan Kimia, 10(2), 1760 - 1768 [in Indonesian].

[11]. Mubarok, A. A., Arthur, R., \& Handoyo, S. S. (2018). Pengembangan Pembelajaran E-Learning Mata Kuliah PTM/Jalan Raya Pendidikan Vokasional Konstruksi Bangunan Fakultas Teknik Universitas Negeri Jakarta. Jurnal Pensil: Pendidikan Teknik Sipil, 7(2), 87-94.

DOI:https://doi.org/10.21009/pensil.7.2.5.

[12]. Munawar, D. M. (2011). Efektifitas Model Blended Learning Dengan Moodle Dalam Meningkatkan Hasil Belajar Siswa Pada Mata Pelajaran Fisika: Studi Pemanfaatan E-Learning di Kelas X SMA Cakra Buana Kota Depok (Doctoral dissertation, Universitas Pendidikan Indonesia).

[13]. Na'imah, N., Supartono, S., \& Wardani, S. (2015). Application of Project-Based Learning Assisted by ELearning to Improve Student Learning Outcomes. Jurnal Inovasi Pendidikan,9(2), 15661574.

[14]. Rohmah, L. (2016). The concept of e-learning and its application in Islamic educational institutions. Jurnal An-Nur, 3(2), 255-270. [in Indonesian].

[15]. Ruffaida, Y. (2017). The role of Navigation Officer in completing Cadet Record Books at Motor Tanker Pegaden. Research Paper, Program Studi Nautika, Program Diploma IV, Politeknik Ilmu Pelayaran Semarang [in Indonesian].

[16]. Sugiyono. (2011). Combination research method. Bandung, Alfabeta. [in Indonesian].

[17]. Yuniyanti, E.D., Sunarno, W., \& Haryono. (2012). Chemistry learning using guided inquiry with module media and e-learning in terms of reading comprehension ability and abstract thinking ability. Jurnal Inkuiri, 1(2), 112-120. [in Indonesian]. 